
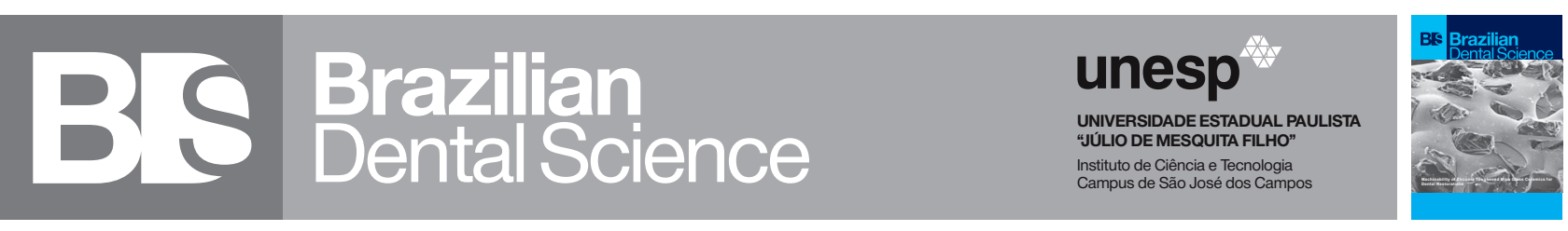

\title{
Cytotoxic Effects of Bulk-Fill Composites on L929 Fibroblast Cells
}

\author{
Efeitos citotóxicos dos compósitos bulk-fill em células de fibroblastos L929 \\ Numan AYDIN ${ }^{1}$, Serpil KARAOĞLANOĞLU' ${ }^{1}$, Elif Aybala OKTAY ${ }^{1}$, Aysun Kılıç SÜLOĞLU² \\ 1 - University of Health Sciences, Gulhane Faculty of Dentistry, Department of Restorative Dental Treatment, Ankara, Turkey. \\ 2 - Hacettepe University, Faculty of Science Department of Biology 06800, Ankara, Turkey.
}

\section{ABSTRACT}

Objective: Unlike traditional composite resins, bulk-fill composite resins could be polymerized as thicker layers. This study aims to contribute to the field by investigating the cytotoxic effects of various bulk-fill composite resins on L929 mouse fibroblast cells in vitro. Material and Methods: In our study, six bulk fill and one conventional composite resin were used. Composite resin samples $(8 \times 4 \mathrm{~mm})$ were prepared in a sterile cabinet by using a glass mod and polymerizing with a led light device (DTE LUX E, Germany). Composite samples (n:3) of which surface area was calculated according to ISO 10993-12: 2012 standards $\left(3 \mathrm{~cm}^{2} / \mathrm{ml}\right)$, were kept in media for $24 \mathrm{~h}$ and $72 \mathrm{~h}$ in $37{ }^{\circ} \mathrm{C}$ incubator, their extracts were filtered in $1: 1$ and $1: 2$ proportion and were added on L929 mouse fibroblast cells. Cell viability was examined by the MTT assay and cell death by the LDH test. Cell viability results were evaluated using one-way analysis of variance (ANOVA) test $(p<0.05)$. Results: When the 1:1 extracts from $4 \mathrm{~mm}$ thick bulk-fill composite samples were applied on L929 mouse fibroblast cells, cell viability rates showed significant differences compared to the control group at the end of $24 \mathrm{~h}$ and $72 \mathrm{~h}$ (except for Estelite Bulk Fill Flow). Although the extracts of the tested composite samples at $1: 1$ and $1: 2$ ratio at the end of 72 hours caused a decrease in L929 mouse fibroblast cell viability, the cell viability rate of only PRG-containing bulk fill composite and conventional composite remained below the cell viability ratio $(70 \%)$ specified in ISO standards. Bulk fill composites did not produce toxic effects (except Beautifil Bulk Restorative) according to the LDH test. Conclusions: Despite decreasing in general the cell viability, bulk-fill

\section{RESUMO}

Objetivo: Ao contrário das resinas compostas tradicionais, as resinas compostas bulk-fill podem ser polimerizadas como camadas mais espessas. Este estudo visa investigar in vitro os efeitos citotóxicos de várias resinas compostas bulk-fill em células de fibroblastos de camundongo L929. Material e Métodos: Em nosso estudo, seis resinas tipo bulk fill e uma resina composta convencional foram usadas. Amostras de resina composta $(8 \times 4 \mathrm{~mm})$ foram preparadas em gabinete estéril usando um molde de vidro e polimerizado com um dispositivo de luz LED (DTE LUX $\mathrm{E}$, Alemanha). Amostras compostas $(\mathrm{n}=3)$ cuja área de superfície foi calculada de acordo com os padrões ISO 10993-12:2012 $\left(3 \mathrm{~cm}^{2} / \mathrm{ml}\right)$, foram mantidas em meio e incubadas por $24 \mathrm{~h} \mathrm{e} 72 \mathrm{~h}$ a $37^{\circ} \mathrm{C}$, seus extratos foram filtrados na Proporção de 1:1 e 1:2 e foram acondicionados em cultura de células de fibroblastos de camundongo L929. A viabilidade celular foi examinada pelo ensaio MTT e a morte celular pelo teste $\mathrm{LDH}$. Os resultados de viabilidade celular foram avaliados usando o teste de análise de variância (ANOVA) um fator $(\mathrm{p}<0,05)$. Resultados: Quando os extratos foram plaqueados na proporção 1:1 de amostras de compósito bulk-fill de $4 \mathrm{~mm}$ de espessura com as células de fibroblastos de camundongo L929, as taxas de viabilidade celular mostraram diferenças significativas em comparação com o grupo controle no final de 24 h e $72 \mathrm{~h}$ (exceto para Estelite Bulk Fluxo de enchimento). Embora os extratos das amostras compostas testadas na proporção de 1:1 e $1: 2$ ao final de 72 horas tenham causado uma diminuição na viabilidade das células de fibroblastos de camundongo L929, a taxa de viabilidade celular apenas do compósito de preenchimento total contendo PRG e o compósito convencional permaneceram abaixo a taxa de viabilidade celular (70\%) especificada nas normas ISO. Os compósitos de preenchimento a granel não produziram efeitos tóxicos (exceto Beautifil Bulk Restorative) de acordo com o teste de LDH. Conclusão: Apesar de diminuir em geral a viabilidade celular, as resinas compostas bulk-fill 
composite resins used in $4 \mathrm{~mm}$ thick layers provided cell viability rates over the acceptability level, except PRG-containing bulk fill composite (Beautifil Bulk Restorative), which was cytotoxic to L929 mouse fibroblasts.

\section{KEYWORDS}

Bulk fill composite; Cytotoxicity; L929 cells; LDH assay. usadas em camadas de $4 \mathrm{~mm}$ de espessura forneceram taxas de viabilidade celular acima do nível aceitável, exceto o compósito bulk fill contendo PRG (Beautifil Bulk Restorative), que foi citotóxico para fibroblastos de camundongos L929.

\section{PALAVRAS-CHAVE}

Compósito Bulk fill; Citotoxicidade; Células L929; Teste LDH.

\section{INTRODUCTION}

A dvancements in restorative materials used in dentistry have enabled the use of composite resins in large cavities in posterior teeth [1]. The fact that composite resins are in tooth color makes these materials advantageous in an esthetic sense $[2,3]$. However, these materials have also disadvantages such as micro leakage and sensitivity occurring due to the polymerization shrinkage $[4,5]$. Also, as the polymerization depth of conventional composite resins is limited to $2 \mathrm{~mm}$, they are recommended to be used in the layering technique for the restoration of the teeth [6]. The incremental placement of the materials requires longer times in restoration and entails certain risks such as air inflow and contamination between the layers [7]. Furthermore, application of the conventional resins into the deep cavities is more difficult due to the limited depth of cure [8].

In recent years, in order to provide composites that are applicable to the cavity in larger masses and as thicker layers, "bulkfill" composites have been introduced. As the new-generation bulk-fill composites allow for higher degrees of polymerization than the conventional composites due to their advanced translucent structures, they could be placed into the cavity in larger masses $(4-6 \mathrm{~mm})[9,10]$. In a study evaluating the clinical performance of bulk-fill composite resins in the restoration of cavities in the posterior teeth, it was stated that there was no difference between conventional and bulkfill composites [11].

Despite the increasing popularity of bulk-fill composite resins, there are concerns about the biocompatibility of these materials. These materials could release monomers in their structures depending on the physical and chemical conditions in oral environment [12]. It is stated in the literature that bisphenol-A glycidyl methacrylate (Bis-GMA), triethylene glycol dimethacrylate (TEGDMA) and urethane dimethacrylate [UDMA] the essential monomers included in the organic matrix of composite resins - create cytotoxic and mutagenic effects on cells [13]. Recently, a nanohybrid ormocer that includes both nanofillers and glass-ceramic fillers has been introduced by the composite industry. Several studies have shown that ormocers release fewer monomer particles and have less cytotoxic effects than the dymethacrylatebased conventional composites. Those studies have carried out the cytotoxicity tests in mouse fibroblasts $[14,15]$.

The aim of this study is to provide a more detailed comparative perspective on the cytotoxicity of bulk-fill composite resins of different contents through an investigation on L929 mouse fibroblast cells using the MTT test in vitro according to ISO 10993-12:2012. The zero hypothesis of the study is that extracts 
from $4 \mathrm{~mm}$ samples of bulk-fill composites will not show cytotoxic effects on L929 mouse fibroblast cells.

\section{MATERIAL AND METHODS}

\section{Preparation of the Samples}

In the study, Grandioso x-tra (Voco, Cuxhaven, Germany), Tetric N Ceram Bulk-Fill (Ivoclar Vivadent, Lihtenştayn), Estelite BulkFill flow (Tokuyama, Tokyo, Japan), Filtek Bulk-Fill Posterior Restorative (3M ESPE, USA), Admira Fusion x-tra (Voco, Cuxhaven, Germany), Beautifil Bulk Restorative (Shofu, Japan) and Filtek Z250 (3M ESPE, USA) composite materials were used (Table I). $8 \times 4$ $\mathrm{mm}$ samples of composites were prepared by using a glass mod in a sterile cabinet and placed in sterile tubes. The composites were polymerized for $20 \mathrm{~s}$ using a DTE LUX E (Germany, $1200 \mathrm{~mW} / \mathrm{cm}^{2}$, tip diameter 8 $\mathrm{mm})$ led device.

Cylinder-shaped samples of composite having a $3 \mathrm{~cm} 2 / \mathrm{ml}$ surface area, which is calculated according to ISO 10993-12: 2012 standards [16], were incubated in 2 $\mathrm{ml}$ serum-free Dulbecco's modified eagle medium (DMEM) (HyClone Laboratories, Inc., Logan, UT, USA) (control group in serum-free medium) for 24 and $72 \mathrm{~h}$, at 37 oC, in an incubator with 5\% CO2. The tubes were covered with pieces of aluminum foil to prevent the composite samples immersed into the serum-free DMEM medium from being exposed to light. The extracts of composite samples were filtered after $24 \mathrm{~h}$ and $72 \mathrm{~h}$ periods, diluted with DMEM medium (1:1 and $1: 2$ ) and cytotoxicity experiments were conducted.
Table I - Bulk fill resin composites and their components

\begin{tabular}{|c|c|c|c|c|c|}
\hline \multirow{2}{*}{ Material } & \multirow{2}{*}{ Type } & \multicolumn{2}{|c|}{ Composition } & \multirow{2}{*}{$\begin{array}{l}\text { Filler } \\
\text { content } \\
(w / w)\end{array}$} & \multirow{2}{*}{$\begin{array}{l}\text { Lot } \\
\text { Number }\end{array}$} \\
\hline & & Matrix & Filler & & \\
\hline $\begin{array}{l}\text { GrandioSO x-tra } \\
\text { (Voco, Cuxhaven, } \\
\text { Germany) }\end{array}$ & Bulk fill & $\begin{array}{l}\text { Bis-GMA } \\
\text { TCDDMA } \\
\text { UDMA }\end{array}$ & $\begin{array}{c}\text { Barium glass } \\
0.4 \mu \mathrm{m} \\
\text { Prepolymer 1-10 } \\
\mu \mathrm{m} \\
\text { Ytterbium trifluori- } \\
\text { de } 100 \mathrm{~nm}\end{array}$ & $77.5-79$ & W93164 \\
\hline $\begin{array}{l}\text { Tetric N Ceram Bulk } \\
\text { Fill (Ivoclar Viva- } \\
\text { dent, Lihtenştayn) }\end{array}$ & Bulk fill & $\begin{array}{l}\text { Dimetha- } \\
\text { crylate }\end{array}$ & $\begin{array}{l}\text { Barium glass,ytter- } \\
\text { bium trifluoride, } \\
\text { mixed oxide, } \\
\text { additives, } \\
\text { catalysts, stabili- } \\
\text { zers, and } \\
\text { pigments }\end{array}$ & $75-77$ & 6643739 \\
\hline $\begin{array}{l}\text { Estelite Bulk Fill } \\
\text { flow (Tokuyama, } \\
\text { Tokyo, Japan) }\end{array}$ & Bulk fill & $\begin{array}{c}\text { Bis-GMA } \\
\text { Bis-MPEPP } \\
\text { TEGDMA } \\
\text { UDMA }\end{array}$ & $\begin{array}{l}\text { Supra-nano } \\
\text { Spherical filler, } \\
\text { Composite Filler } \\
\text { (200 nm spherical } \\
\text { Si02-Zr02) }\end{array}$ & 70 & W114 \\
\hline $\begin{array}{l}\text { Filtek Bulk Fill } \\
\text { Posterior Restora- } \\
\text { tive (3M ESPE St. } \\
\text { Paul,USA) }\end{array}$ & Bulk fill & $\begin{array}{l}\text { AUDMA } \\
\text { UDMA } \\
\text { DDDMA } \\
\text { EDMAB }\end{array}$ & $\begin{array}{l}\text { ytterbium trifluori- } \\
\text { de, ceramic/slica/ } \\
\text { zirconia }\end{array}$ & 76,5 & 100372 \\
\hline $\begin{array}{l}\text { Admira Fusion x-tra } \\
\text { (Voco, Cuxhaven, } \\
\text { Germany) }\end{array}$ & Bulk fill & - & $\begin{array}{l}\text { Inorganic fillers (Or- } \\
\text { ganically modified } \\
\text { ceramics) }\end{array}$ & 84 & 1704051 \\
\hline $\begin{array}{l}\text { Beautifil Bulk } \\
\text { Restorative (Shofu, } \\
\text { Japan) }\end{array}$ & Bulk fill & $\begin{array}{l}\text { Bis-GMA } \\
\text { UDMA } \\
\text { Bis-MPEPP } \\
\text { TEGDMA }\end{array}$ & $\begin{array}{c}\text { S-PRG } \\
\text { filler based on } \\
\text { fluoroboroalumino- } \\
\text { silicate glass }\end{array}$ & 87 & 1815363 \\
\hline $\begin{array}{l}\text { Filtek Z250 (3M } \\
\text { ESPE St.Paul,USA) }\end{array}$ & $\begin{array}{l}\text { Conven- } \\
\text { tional (Mi- } \\
\text { crohybrid) }\end{array}$ & $\begin{array}{c}\text { Bis-GMA } \\
\text { UDMA } \\
\text { TEGDMA } \\
\text { PEGDMA } \\
\text { Bis-EMA }\end{array}$ & $\begin{array}{l}\text { Silika filler } 20 \mathrm{~nm} \text { ve } \\
\text { 4-11nm zirkonyum }\end{array}$ & 78.5 & N717544 \\
\hline
\end{tabular}

*BisGMA: Bisfenol diglisidilmetakrilat, BisEMA: bisfenoletilmetakrilat, UDMA: üretan dimetakrilat, PEGDMA: polietilen glikol dimethacrylate, TEGDMA: trietilenglikol dimethacrylate; Bis-MEPP: 2,2-bis (4-methacryloxypolyethoxyphenyl) propane.

\section{Cell Culture}

The L929 fibroblast cell line stored at $-196{ }^{\circ} \mathrm{C}$ was let thaw in a water bath at 37 ${ }^{\circ} \mathrm{C}$ and centrifuged. The cells were kept in DMEM, which is supplemented with $10 \%$ fetal bovine serum (PAA Laboratories, Linz, Austria), at $37{ }^{\circ} \mathrm{C}$ and $5 \% \mathrm{CO}_{2}$ in a humidified incubator. Once the cells reached the optimal density $(1 \times 105$ cells $/ \mathrm{ml})$, the cell suspension was prepared according to the descriptions in ISO 10993-5: 2009 [17] by calculating the cell number of the desired density for a 96well cell culture plate using DMEM medium including 10\% FBS and 1\% antibiotic. 
Then the cell suspension was allocated into the 96-well cell culture plate $[100 \mu \mathrm{l} /$ well] and incubated for $24 \mathrm{~h}$ in a 5\% CO2 incubator. After the incubation, DMEM was removed and the media remaining of the two different dilutions, in which the composites were immersed, were similarly allocated into wells $(100 \mu \mathrm{l} /$ well $)$ and the materials were incubated for another $24 \mathrm{~h}$ in a 5\% CO2 incubator. Finally, the MTT assay was performed.

\section{Cytotoxicity Test}

MTT ([3- [4,5-dimethylthiazol-2-yl] -2,5-diphentyltetrazolium bromide), Sigma, USA] was combined with PBS, homogenized and an MTT solution with a final concentration of $5 \mathrm{mg} / \mathrm{ml}$ became ready for the cell viability test. The secreted media in 96-well cell culture plate that were incubated for $24 \mathrm{~h}$ was removed after incubation, then $100 \mu \mathrm{l} /$ well DMEM medium and $13 \mu \mathrm{l} /$ well MTT solution were filled in clusters and incubated at $37{ }^{\circ} \mathrm{C}$ in a dark environment for $4 \mathrm{~h}$. After that, the MTT solution was removed from the medium by aspiration. $100 \mu \mathrm{l} /$ well Ammonia-Dimethyl sulfoxide $(5: 100)$ mixture was poured into 96-well cell culture plate; and at the optical reader, the absorbance rates were read at 550 $\mathrm{nm}$ (BIO-TEK $\mu$ Quant, BIO-TEK Instruments, Inc, USA) then, the results were compared with the control wells.

\section{Lactate dehydrogenase (LDH) Leakage Assay}

The lactate dehydrogenase assay (LDH) for cytotoxicity was performed on the extracts (1:1 ratio) of the bulk fill composite samples after $72 \mathrm{~h}$ according to the instructions given in the commercial kit. In brief, L929 cells were cultured in a 96-well plate at $1 \times 104$ cells/ well density and incubated in a humidified atmosphere $(5 \% \mathrm{CO} 2)$ at $37{ }^{\circ} \mathrm{C}$ for $24 \mathrm{~h}$. After removing the culture media, cells were exposed to extracts of the composite samples.
After collecting the existing culture media, it was centrifuged at $600 \mathrm{~g}$ for $10 \mathrm{~min}$. Then, $100 \mu \mathrm{l}$ of $\mathrm{LDH}$ reaction mix was added onto $10-\mu 1$ supernatant of sample and incubated for another $30 \mathrm{~min}$ at room temperature. Absorbance levels of the samples were read at $450 \mathrm{~nm}$ and $650 \mathrm{~nm}$ reference wavelength in microplate spectrophotometer (BIO-TEK $\mu$ Quant, BIO-TEK Instruments, Inc, USA). All experiments were triplicated. Cytotoxicity percent was calculated as: (absorbance of sample - absorbance of control sample) / (absorbance of high control sample absorbance of control sample) $\times 100$.

\section{Statistical Analysis}

Statistical analysis of the data was performed using the SPSS 22.0 program (SPSS Inc., Chicago, IL, USA). Cell viability rates belonging to the $1: 1$ and $1: 2$ diluted extracts of the composite samples obtained at the end of $24 \mathrm{~h}$ and $72 \mathrm{~h}$ periods were compared by using one-way analysis of variance (ANOVA) and Tukey multiple comparison tests $(\mathrm{p}<0.05)$.

\section{RESULTS}

Bulk fill composite resins tested, only Filtek Bulk Fill Posterior and Beautifil Bulk Restorative extracts $(1: 1)$ at the end of $24 \mathrm{~h}$ showed significant differences in cell viability compared to the control group ( $\mathrm{p}<0.05)$. The cell viability values of the extracts $(1: 2)$ of these composite resins (except Beautifil Bulk Restorative) did not differ significantly compared to the control group ( $\mathrm{p}>0.05)$, (Table II).

At the end of $24 \mathrm{~h}$, the fluid bulk-fill composite extract showed the highest cell viability among the composite sample extracts, while the pre-reacted glass-ionomer (PRG) containing bulk-fill composite (Beautifil Bulk Restorative) provided the lowest rate. Although the organically modified ceramic- 
based (ormocer) bulk-fill composite (Admira Fusion x-tra) exhibited a higher rate of cell viability than PRG-based composite and Filtek Bulk Fill Posterior composite, it did not show a statistically significant difference compared to the other bulk-fill composites.

At the end of $72 \mathrm{~h}$, both $1: 1$ and $1: 2$ extracts of the samples showed significant results in terms of cell viability, in comparison to the control group $(\mathrm{p}<0.05)$, except for Estelite Bulk Fill Flow. Beautifil Bulk Restorative composite exhibited the lowest rate of cell viability $(\mathrm{p}<0.05)$, (Table III). When the extracts of bulk-fill composites at the end of 24 and 72 were diluted by $1: 2$ the cell viability increased (Table II and III). At the end of $72 \mathrm{~h}$, Beautifil Bulk Restorative and conventional composite (Filtek Z250) remained below the ISO cell viability standard $(70 \%)$ at $1: 1$ (Table III and Figure 1 ) and 1:2 dilution (Table III).

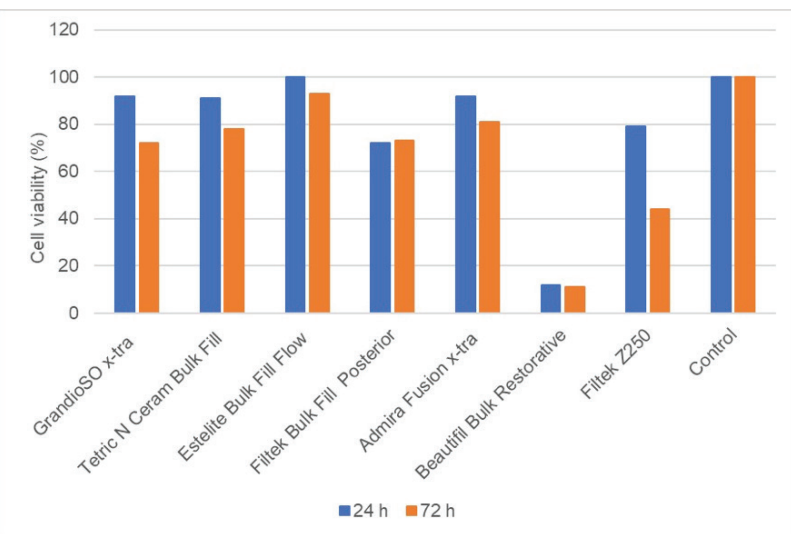

Figure 1 - Cytotoxicity (MTT test) results of the extracts (1:1) of composites in L929 cells after 24 and $72 \mathrm{~h}$ incubation. The results (mean) of three independent experiments are shown as $\%$ of the untreated control.

When the LDH test results of the extracts of composites (1:1 ratio after 72 h) are examined; The increase in the $\mathrm{LDH}$ activity of the Beautifil Bulk Restorative and conventional composite (Filtek Z250) groups was statistically significant compared to the control group $(\mathrm{p}<0.05)$. The use of Beautifil Bulk Restorative composite induced 45.9\% cell death in L929 cells according to LDH release assay which indicated the breakdown (necrosis) of the cell membrane (Figure 2).

Table II - Cell viability percentage of the extracts of the composites at the end of $24 \mathrm{~h}$ according to MTT test

\begin{tabular}{|c|c|c|c|c|}
\hline \multirow{2}{*}{ Material } & \multicolumn{2}{|c|}{ Cell absorbance value } & \multicolumn{2}{|c|}{ Cell Viability (\%) } \\
\hline & (1:1) & (1:2) & $(1: 1)$ & $(1: 2)$ \\
\hline GrandioSO $x$-tra & $1.03 \pm 0.05 a$ & $1.04 \pm 0.06 a$ & 92.8 & 93.6 \\
\hline $\begin{array}{l}\text { Tetric N-Ceram } \\
\text { Bulk Fill }\end{array}$ & $1.02 \pm 0.16 \mathrm{a}$ & $1.18 \pm 0.16 a$ & 91.9 & 107.3 \\
\hline $\begin{array}{l}\text { Estelite Bulk Fill } \\
\text { Flow }\end{array}$ & $1.12 \pm 0.13 a$ & $1.21 \pm 0.29 a$ & 100.9 & 109.0 \\
\hline $\begin{array}{l}\text { Filtek Bulk Fill } \\
\text { Posterior }\end{array}$ & $0.80 \pm 0.09 b$ & $0.97 \pm 0.11 a$ & 72.1 & 87.4 \\
\hline Admira Fusion $\mathrm{x}$-tra & $1.09 \pm 0.04 a$ & $1.12 \pm 0.08 \mathrm{a}$ & 92.2 & 100.9 \\
\hline $\begin{array}{l}\text { Beautifil Bulk } \\
\text { Restorative }\end{array}$ & $0.14 \pm 0.02 \mathrm{c}$ & $0.52 \pm 0.07 \mathrm{~b}$ & 12.6 & 46.8 \\
\hline FiltekZ250 & $0.88 \pm 0.09 b$ & $1.02 \pm 0.13 a$ & 79.3 & 91.9 \\
\hline Control & $1.11 \pm 0.03 a$ & $1.10 \pm 0.06 a$ & 100 & 100 \\
\hline
\end{tabular}

* Different letters indicate statistical difference between the groups. $p<0.05$.

Table III - Cell viability percentage of the extracts of the composites at the end of $72 \mathrm{~h}$ according to MTT test

\begin{tabular}{|c|c|c|c|c|}
\hline \multirow{2}{*}{ Material } & \multicolumn{2}{|c|}{ Cell absorbance value } & \multicolumn{2}{|c|}{ Cell Viability (\%) } \\
\hline & (1:1) & $(1: 2)$ & $(1: 1)$ & (1:2) \\
\hline GrandioSO $x$-tra & $1.16 \pm 0.09 a$ & $1.17 \pm 0.12 \mathrm{a}$ & 72.1 & 78.0 \\
\hline $\begin{array}{l}\text { Tetric N-Ceram } \\
\text { BulkFill }\end{array}$ & $1.26 \pm 0.13 a$ & $1.22 \pm 0.08 \mathrm{a}$ & 78.3 & 81.3 \\
\hline $\begin{array}{l}\text { Estelite Bulk Fill } \\
\text { Flow }\end{array}$ & $1.50 \pm 0.17 \mathrm{bc}$ & $1.52 \pm 0.12 b$ & 93.1 & 101.3 \\
\hline $\begin{array}{l}\text { Filtek Bulk Fill } \\
\text { Posterior }\end{array}$ & $1.19 \pm 0.08 \mathrm{a}$ & $1.25 \pm 0.14 a$ & 73.9 & 83.3 \\
\hline Admira Fusion $\mathrm{x}$-tra & $1.32 \pm 0.10 \mathrm{ab}$ & $1.12 \pm 0.14 \mathrm{a}$ & 81.2 & 74.6 \\
\hline $\begin{array}{l}\text { Beautifil Bulk } \\
\text { Restorative }\end{array}$ & $0.18 \pm 0.01 e$ & $0.43 \pm 0.10 \mathrm{~d}$ & 11.2 & 28.7 \\
\hline FiltekZ250 & $0.71 \pm 0.18 \mathrm{~d}$ & $0.91 \pm 0.16 c$ & 44.1 & 60.7 \\
\hline Control & $1.61 \pm 0.13 \mathrm{c}$ & $1.50 \pm 0.19 b$ & 100 & 100 \\
\hline
\end{tabular}

* Different letters indicate statistical difference between the groups. $p<0.05$.

\section{DISCUSSION}

Bulk-fill composite resins are commonly preferred by dentists for the restoration of 
teeth as they could be applied in thick layers. However, due to the failure of led light to reach a sufficient depth during the polymerization of these materials, the insufficiently polymerized monomer particles may remain free in their structure. It has been reported that the biocompatibility of composite resins is correlated with the amount and structure of the organic substances released [18] and monomers released from the resin matrix because of the insufficient polymerization may produce cytotoxic results over time $[19,20]$. In our in vitro study, we tried to examine the cytotoxic effects occurring on L929 mouse fibroblast cells depending on the use of bulk-fill resins of different contents in 4 mm thickness.

ISO 10993-12: 2012 proposed several cell culture testing models to evaluate the cytotoxicity of dental materials [16]. These are direct contact (direct method), indirect contact with a barrier (indirect method), and the extract method in which the extracts from biomaterials are added onto the cells. In the ISO 10993-5: 2009 standard, it was stated that the tested materials may have toxic potential if the cell vitality is below 70\% after MTT test [17]. Lim et al. [21] compared those in vitro test models use to evaluate the cytotoxicity of composite resins and suggested the extract test due to its higher sensitivity if a single test model is planned to be used in the studies.

L929 mouse fibroblast cell lines are the most widely used cells to evaluate the in vitro cytotoxicity of dental materials [22,23]. Among the major advantages of mouse fibroblast cell lines it is stated that they are practical to use, contain one single type of cell and provide more accurate cytotoxic responses [23]. Therefore, in our study L929 mouse fibroblast cell line was preferred.

It is stated that the extent to which the polymerization of the restorative composite resins is accomplished, has an impact on the toxicity [24], and the oxygen inhibition layer formed on the surface of the composites after polymerization increases the monomer release [25]. In their study evaluating the cytotoxicity of the composites, Couchman et al. [26] suggested that the curing time decreased cytotoxicity by increasing the degree of polymerization. In the literature, it is also reported that there is no correlation between the oxygen inhibition layer formed during the polymerization of the samples by covering them with a glass and the amount of monomer release [27]. In our study, composite materials were covered with $1 \mathrm{~mm}$ glass coverslip and polymerized for 20 seconds with high intensity (DTE LUX E, Germany, $1200 \mathrm{~mW} / \mathrm{cm}^{2}$ ) led light device.

In a study on the toxicity of bulk-fill composites carried out on mouse fibroblast cells, Toh et al. [28] reported that extracts obtained from $4 \mathrm{~mm}$ samples showed more cytotoxicity than $2 \mathrm{~mm}$ samples. In a similar study on the toxicity of fluid and paste bulkfill composite resins conducted on L929 mouse fibroblasts by Demirel et al. [29] it was reported that at the end of $72 \mathrm{~h}$ composite extracts caused a statistically significant decrease in cell viability level, which is in line with the former. In a study on human pulp cells, by examining the toxic effect of bulkfill composite samples in terms of whether it change at the layers of different polymerization depths [0-2, 2-4 and 4-6 mm] Lee et al. [30] stated that as the irradiation depth increased the more toxicity occurred, and the highest cytotoxicity was observed in the layer of 4-6 mm depth. However, Nascimento et al. [31] reported that bulk-fill resins exhibited low level and/or no cytotoxicity on L929 cells, except for Opus, which showed more moderate cytotoxicity, as pointed out in the MTT assay index.

In our study, at the end of $72 \mathrm{~h}$, the cell 
viability rate of the Estelite Bulk Fill Flow composite used as $4 \mathrm{~mm}$ layers did not cause a statistically significant difference compared to the control group. However, ormocer-based (Admira Fusion x-tra), PRG-containing bulkfill composite (Beautifil Bulk Restorative) and the other bulk-fill composites (GrandiosO x-tra, Tetric N-Ceram Bulk Fill, Filtek Bulk Fill Posterior) caused a significant reduction in the cell viability. As the bulk-fill composites diminished the viability of L929 mouse fibroblast cells, the null hypothesis of the study was rejected.

Legraand et al. [32] the release of LDH culture medium as a result of damage to the cell membrane indicates cell death. Increased LDH activity is associated with an increase in dead cell numbers and a decrease in glucose consumption. In our study, Beautiful Bulk Restorative and conventional composite (Filtek Z250) showed more LDH activity than the control group with extracts in the ratio of $1: 1$ after $72 \mathrm{~h}$. Our results were in accordance with Legrand.

Schubert et al. [33] found that Admira Fusion had significantly less cytotoxic effect on mouse L929 cells and human gingival fibroblasts than Filtek Supreme XTE and GrandioSO. The absence of certain classic resin monomers in Admira Fusion apparently allowed for lower cytotoxicity and better biocompatibility, compared to resinbased dental restoratives, which is of great importance for the clinical practice. In our study, bulk-fill composite (Admira Fusion $\mathrm{x}$-tra) containing ormocer caused a significant decrease in cell viability at the end of $72 \mathrm{~h}$ compared to the control group, even if it did not at the end of $24 \mathrm{~h}$.

It is stated that both the resin content of the composites and the degree of monomer conversion play a determining role in cytotoxicity levels [34]. Although bulk-fill composites have many advantages, there could remain some unpolymerized monomers at a depth of $4 \mathrm{~mm}$. Those monomers, BisGMA, TEGDMA and UDMA, released from the structure of composites have been proven to be cytotoxic in many studies $[35,36]$. The toxicity grading of these monomers has been reported to be as Bis-GMA > UDMA> TEGDMA [36]. In our study, Estelite Bulk Fill Flow, which has similar monomers (BisGMA, Bis-MPEPP, TEGDMA, UDMA), showed the highest cell viability, while Beautifil Bulk Restorative showed the lowest one.

In this study, Beautifil Bulk Restorative was observed to cause a significant reduction in cell viability in both 24 and $72 \mathrm{~h}$ of experimentation periods. This product contains PRG filler in its resin matrix, unlike the other tested bulk-composites. The fluoro-aluminosilicate glass is pre-reacted with polyacid by forming a glass-ionomer matrix structure and blended with resin. Resin-based restorative materials containing PRG filler have been reported to provide higher fluoride release than compomers due to their glass ionomer hydrogel matrices [37]. In line with the results of this study, in a previous study, Toh et al. [28] found that Beautifil Bulk Restorative was to be more cytotoxic than all other tested bulk-fill composites. They suggested that the cytotoxic effects of Beautifil Bulk Restorative might be caused by the release of fluoride and other ions, such as PRG fillers including aluminum, boron, sodium, silicon, strontium, and zinc.

In the previous literature on the toxic effects of conventional composites on L929 mouse fibroblasts, it was stated that the decrease in cell viability after the first $24 \mathrm{~h}$ was not significant, while it was observed to reach more significant levels after $72 \mathrm{~h}[33,38]$. The data obtained in our study shows that composites keep releasing cytotoxic materials after the first $24 \mathrm{~h}$ following polymerization. 
Furthermore, the reduction in cell viability turned out to be higher in the $72 \mathrm{~h}$ extracts.

The findings of this in vitro study, which aimed to examine the cytotoxic effects of bulk-fill composites, are limited to the data collected on a single type of cell line and a two types of cytotoxicity test applied. Then, our study provides only a general and elementarylevel evaluation about the cytotoxicity of bulkfill composites. The tests models applied onto different cell lines or cells that are sourced from humans' oral environment could give different responses in terms of cytotoxicity.

\section{CONCLUSION}

At the end of $72 \mathrm{~h}$, the majority of bulkfill composites decreased the cell viability but they did not cause unacceptable cytotoxic effects to L929 mouse fibroblasts, except PRGcontaining bulk fill composite (Beautifil Bulk Restorative), which was cytotoxic.

\section{Acknowledgments}

During the development, writing and critical review of the manuscript., no coordination or individual assistance was received except for the authors.

\section{Funding}

The study was not funded by any grants or external funding.

\section{Conflict of interest}

The authors have no proprietary, financial, or other personal interest of any nature or kind in any product, service, and/or company that is presented in this article.

\section{Regulatory Statement}

This study was conducted in accordance with all the provisions of the local human subjects oversight committee guidelines and policies of: World Medical Association Declaration of Helsinki.

\section{REFERENCES}

1. Fugolin APP,Pfeifer CS. New resins for dental composites. JDent Res. 2017 Sep:96(10); 1085- 91. doi: 10.1177/0022034517720658. Epub 2017 Jul 21.

2. Fonseca AS, Labruna Moreira AD, de Albuquerque PP, de Menezes LR, Pfeifer CS, Schneider LF. Effect of monomer type on the CC degree of conversion, water sorption and solubility, and color stability of model dental composites. Dent Mater. 2017 Apr;33(4):394-401. doi: 10.1016/j. dental.2017.01.010. Epub 2017 Feb 27.PMID:28245929.

3. Huang B, Siqueira WL, Cvitkovitch DG, Finer Y. Esterase from a cariogenic bacterium hydrolyzes dental resins. Acta Biomaterialia. 2018 Apr; 71:330-8.

4. Tantbirojn D, Pfeifer CS, Braga RR, Versluis A. Do low-shrink composites reduce polymerization shrinkage effects? J Dent Res. 2011 May; 90(5):596601.

5. Politi I, McHugh LEJ, al-Fodeh RS, Fleming GJP. Modification of the restoration protocol for resin-based composite (RBC) restoratives (conventional and bulk fill) on cuspal movement and microleakage score in molar teeth. Dent Mater. 2018 Sep;34(9):1271-77.

6. Leprince JG, Palin WM, Hadis MA, Devaux J, Leloup G. Progress in dimethacrylate-based dental composite technology and curing efficiency. Dent Mater. 2013 Feb;29(2): 139-56.

7. Şişman R, Aksoy A, Yalçın M, KaraözE. Cytotoxic effects of bullk fill composite resins on human dental pulp stem cells. J Oral Sci. 2016 Feb; 58(3):299-305.

8. Han SH and Park SH. Incremental and bulk-fill techniques with bulk-fill resin composite in different cavity configurations. Oper Dent. 2018 Nov/Dec; 43(6):631-41.

9. Aydın N, Karaoğlanoğlu S, Oktay EA, Toksoy Topçu F, Demir F. Bulk fill composite resins in dentistry. Selcuk Dental Journal. 2019; 6(2):229-38

10. Garcia D, Yaman P, Dennison J, Neiva GF. Polymerization shrinkage and depth of cure of bulk fill flowable composite resins. Oper Dent. 2014 Jul/Aug; 39(4):441-48

11. Veloso SRM, Lemos CAA, de Moraes SLD, Do Egito Vasconcelos BC, Pellizzer EP, de Melo Monteiro GQ. Clinical performance of bulk-fill and conventional resin composite restorations in posterior teeth: a systematic review and meta-analysis. Clin Oral Invest. 2019 Jan;23:221-33. https://doi.org/10.1007/ s00784-018-2429-7

12. Reichl FX, Seiss M, Kleinsasser N, Kehe K, Kunzelmann KH, Thomas P, et al. Distribution and excretion of BisGMA in guinea pigs. J Dent Res. 2008 Apr; 87(4):378-80.

13. Geurtsen W, Lehmann F, Spahl W, et al. Cytotoxicity of 35 dental resin composite monomers/additives in permanent 3 T3 and three human primary fibroblast cultures. J Biomed Mater Res. 1998 Dec; 41(3):474-80.

14. Susila AV, Balasubramanian V. Correlation of elution and sensitivity of cell lines to dental composites. Dent Mater. 2016 Mar; 32(3):63-72.

15. Moszner N, Gianasmidis A, Klapdohr S, Fischer UK, Rheinberger V. Sol-gel materials 2. Light-curing dental composites based on ormocers of crosslinking alkoxysilane methacrylates and further nano-components. Dent Mater. 2008 Jun; 24(6):851-56

16. ISO 10993-12:2012. Biological evaluation of medical devices. Part 12: Sample preparation and reference materials, Geneva, 2012.

17. IS0 10993-5:2009. Biological evaluation of medical devices. Part 5: Tests for in vitro cytotoxicity. Geneva, 2009

18. Eckhardt A, Harorli T, Limtanyakul J, Hiller KA, Bos I C, Bolay C, et al. Inhibition of cytokine and surface antigenexpression in LPS-stimulated murine 
macrophages bytriethylene glycol dimethacrylate. Biomaterials. $2009 \mathrm{Mar}$; 30(9):1665-74.

19. Geurtsen W. Biocompatibility of resin-modified filling materials. Critical Reviews in Oral Biology \&Medicine. $2000 \mathrm{Jul} ;$ 11(3):333-55.

20. Ferracane J. Elution of leachable components from composites. Journal of Oral Rehabilitation. 1994 Jul; 21(4): 441-52

21. Lim SM, Yap AUJ, Loo CSL, Ng J, Goh CY, CHL Hong, et al. Comparison of cytotoxicity test models for evaluating resin-based composites. Human \& Experimental Toxicology.2017 Apr;36(4):339-48

22. Thonemann B, Schmalz G, Hiller KA, Schweikl H. Responses of L929 mouse fibroblasts, primary and immortalized bovine dental papilla-derived cell lines to dental resin components. Dent Mater. 2002 Jun; 18(4):318-23.

23. Saw TY, Cao T, Yap AUJ, Lee Ng MM. Tooth slice organ culture and established cell line culture models for cytotoxicity assessment of dental materials. Toxicology in Vitro. 2005 Feb; 19(1):145-54

24. Cao T, Saw TY, Heng BC, Liu H, Yap AU, Ng ML. Comparison of different test models for the assessment of cytotoxicity of composite resins. J Appl Toxicol. 2005 Mar; 25(2):101-8.

25. Pulgar R, Olea-Serrano MF, Novillo-Fertrell A, Rivas A, Pazos P, Pedraza V.et al. Determination of bisphenol $A$ and related aromatic compounds released from bis-GMA-based composites and sealants by high performance liquid chromatography. Environ Health Perspect. 2000 Jan; 108:21-7.

26. Caughman WF, Caughman GB, ShiflettRA, Rueggeberg F, Schuster GS. Correlation of cytotoxicity, filler loading and curing time of dental composites. Biomaterials. 19910ct; 12(8):737-40.

27. Van Landuyt KL, Nawrot T, Geebelen B, De Munck J, Snauwaert J, Yoshihara K. et al. How much do resin-based dental materials release? A metaanalytical approach. Dent Mater.2011 Aug; 27(8): 723-47.

28. Toh WS, Yap AU, Lim SY. In vitro biocompatibility of contemporary bulk-fill composites. Oper Dent. 2015 Nov/Dec;40(6):644-52.
29. Demirel G, Gür G, Demirsoy FF, Altuntas EG, Yener-illce B, Killçarslan MA. Cytotoxic effects of contemporary bulk-fill dental composites: A real-time cell analysis. Dental Materials Journal. 2020; 39:101-10.

30. Lee SM, Kim SY, Kim JH, Jun SK, Kim HW, Lee JH, et al. Depth-dependent cellular response from dental bulk-fill resins in human dental pulp stem cells. Stem Cells International. 2019 0ct;1-12

31. Nascimento AS, Lima DB, Fook MVL, Albuquerque MS, Lima EA, Sabino MA, et al. Physicomechanical characterization and biological evaluation of bulkfill composite resin. Braz Oral Res .2018 0ct;32:e107.

32. Legrand C, Bour JM, Jacob C, Capiaumont J, Martial A, Marc A, et al. Lactate dehydrogenase [LDH] activity of the number of dead cells in the medium of cultured eukaryotic cells as marker. Journal of Biotechnology. 1992 Sep;25(3):231-43

33. Schubert A, Ziegler C, Bernhard A, Bürgers R, Miosge N. Cytotoxic effects to mouse and human gingival fibroblasts of a nanohybrid ormocer versus dimethacrylate-based composites. Clin Oral Invest. 2019 Jan;23:133-39. https://doi.org/10.1007/s00784-018-2419-9

34. Goldberg M. In vitro and in vivo studies on the toxicity of dental resin components: a review. Clin Oral Invest. 2008 Mar; 12:1-8. https://doi. org/10.1007/s00784-007-0162-8

35. Harorli OT, Bayindir YZ, Altunkaynak Z, Tatar A. Cytotoxic effects of TEGDMA on THP-1 cells in vitro. Med Oral Patol Oral Cir Bucal. 2009; 14:489-93.

36. Moharamzadeh K, Noort RV, Brook IM, Scutt AM. Cytotoxicity of resin monomers on human gingival fibroblasts and HaCaT keratinocytes. Dent Mater. 2007 Jan; 23(1): 40-4.

37. Itota T, Carrick TE, Yoshiyama M, Scutt AM. Fluoride release and recharge in giomer, compomer and resin composite. Dent Mater. 2004 Nov; 20(9): $789-95$.

38. Aydın N, Karaoğlanoğlu S, Oktay EA, Süloğlu AK. Evaluating of Cytotoxic Effects of Highly Esthetic Dental Composites. Braz Dent Sci. 2020 Jan/Mar; 23:1-8.

\section{Numan Aydin DDS, PhD}

(Corresponding address)

University of Health Sciences, Gulhane Faculty of Dentistry, Department of Restorative Den-

tal Treatment, Etlik 06018 Ankara, Turkey

Date submitted: 2019 Apr 09

Email: dt_numan@hotmail.com
Accept submission: 2020 Jul 16 